Надія Братюк Nadiia Bratiuk

аспіранка кафедри історії і теорії мистецтв

Аьвівської національної академії мистецтв postgraduate student, Department of History and

Theory of Arts, Lviv National Academy of Arts

\title{
Експресивно-живописна мова
}

\section{та націонамьний вектор творчих пошуків} Аьвівських митців 1980-х років:

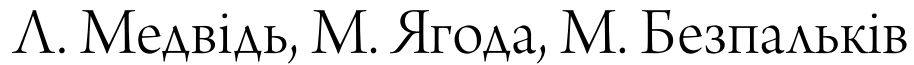 \\ Expressive and Pictorial Language \\ and the National Orientation of Creative Experiements \\ of the Lviv Artists in the 1980s: \\ L. Medvid, M. Yagoda, M. Bezpalkiv
}

\begin{abstract}
Анотація. АосліАжено експресивно-живописні засоби у творчості Аьвівських митців 1980-х років - . МедвіАя, М. Ягоди, М. Безпальківа - знакових постатей другої половини XX століття у художньому житті Аьвова, віАомих в Україні та за корАоном. Їхні роботи суттєво вирізняються на тлі художнього контексту, полотна апелюють до глибоких духовних і морально-естетичних вартостей, української міфології та традиції, відзначаються професіоналізмом і власним стилем.

Метою досліАження стала живописна творчість $\Lambda$. МеАвіАя, М. Ягоди, М. Безпальківа 1980-х років у контексті експресіоністичного вектору розвитку. Проаналізовано полотна, в яких експресіоністична складова зароджується або виразно простежується. Зібраний візуальний матеріал, а також наукові публікації, що стосуються творчості зазначених митців, разом утворюють багату й унікальну картину мистецьких процесів. Методику АосліАження склаАають мистецтвознавчий аналіз, порівняльний метоА, метоА аналізу і синтезу, формальний аналіз стильових рис авторського живописного почерку. У процесі комплексного АосліАження з'ясовано соціокультурні, мистецькі та політичні передумови, які спричинили появу та становлення саме експресивних рис у творчості $\Lambda$. МеАвіАя, М. Ягоди, М. Безпальківа. Виявлено, що живопис Аьвів'ян 1980-х років суттєво вплинув на сучасне мистецтво Аьвова.
\end{abstract}

Ключові слова: вісімдесятники, $\Lambda$. Медвідь, М. Ягода, М. Безпальків, експресивно-живописна мова, живопис, Аьвівські митці.

Постановка пробмеми. Момент самоідентифікації та пізнання глибинної філософії та Ауховності в мистецтві, пошук пластичної мови, що була 6 характерною саме Аля українського народу та втілювала 6 його національну специфіку, є непростими завданнями, які активно розв'язували мьвівські художники у $1980-x$ років. Митці у своїх роботах по-новому переосмислюють та інтерпретують побутову тематику в зовсім іншому, сучасному, експресивному контексті, який $є$ антиподом до соціалістичної мистецької системи коорАинат.

Аналіз останніх досліАжень і публікацій. Тема статті розгляАається з позиції експресивно-живописної мови в індивідуальних живописних розвідках у межах окресленого хронологічного періоду. Аналізуючи проблематику Аьвівського АосвіАу 1960-1980-х років, АосліАниця М. Мусій [4] акцентує увагу на живописній творчості опозиційних художників-Аьвів'ян старшого і молоАшого поколінь.
Якісний візуальний матеріал подано в альбомах «Михайло Безпальків» (1999) [15], «Михайло Безпамьків» (2012) [18], «МеАвіАь Аюбомир. Ремінісценції» (2010) [9], «МеАвіАь $\Lambda$. ПараА парабол» (2015) [19],

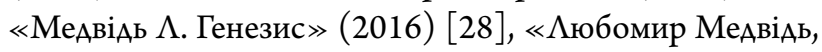
Олег Мінько, Зеновій ФАінта» (1981) [20], каталогах «Аюбомир МеАвіАь, Олег Мінько, Зеновій Фмінта» (1986) [21], «МеАвіАь А. Живопис» (1987) [22], « юбомир МеАвіАь, Олег Мінько, Зеновій ФАінта» (1992) [23], «Незалежному культурологічному часописі “Ї” » (1989) [27], у працях «Мирослав Ягода. Графіка» (2019) [24], «Мирослав Ягода. Живопис» (2019) [25].

Важиивим кроком упереА стали статті О. Петрової [1], А. Волошин [3], Г. Островського [5; 8], М. РуАенко [14], А. Бондаренко [13], І. Ткачук [16]. Анаміз мьвівського мистецького процесу з позиції експресивних тенАенцій як цілісного явища, на нашу думку, важливий, 
і потребує більш точного, Аеталізованого та систематизованого викладу матеріалу. Переглянувши велику кількість публікацій, можемо зробити висновок про недостатнє висвітлення та розкриття обраної теми.

Мета статті: Аослідити живописну творчість та виявити характерні риси творчості $\Lambda$. МеАвіАя, М. ЯгоАи, М. Безпальківа в контексті експресіоністичного вектору розвитку.

ВикмаА основного матеріалу досліАження. Мистецька ситуація у Аьвові 1980-х років сприяла віАродженню та експонуванню живописних рефлексій на полотні. Більш детально експресивно-живописну мову того часу можна розглянути на прикладі індивіАуальних художньообразних пошуків $\Lambda$. МеАвіАя, М. ЯгоАи, М. Безпальківа. Саме в 1980-х роках експресіоністичні тенденції найбільш виразні в творчості М. Безпальківа, є унікацьними та метафоричними з огляду на наявність психічних розмадів у помотнах М. Ягоди, сформовані та присутні у Аеяких полотнах $\Lambda$. МеАвіАя.

СереА яскравих преАставників мьвівського осереАку варто виділити художника-мислитемя Аюбомира МеАвіАя, оАного зі знакових і гмибоко шанованих постатей 1980-2000-х років не тільки на Аьвівських, а й на загальноукраїнських і світових теренах. Його творчість і Аотепер хвилює АосліАників графічно-конструктивно-експресивною манерою, в якій органічно поєАнано елементи різних течій - віА реалістично промальованих миків і постатей Ао експресіоністичних кольорових поєАнань, сюрреалістичних Аинамічних рухів, гіперреалістичних композиційних структур. У період тоталітарної дійсності митець став яскравим прикладом неформальних пошуків. У статті О. Петрової «ТрагеАійний абсурдизм у живописі

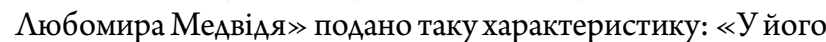
полотнах 70-80-х років є ознаки нового хронотипу. ХуАожник фіксує знецінювання “гомо сапіенс" у суспільстві, Ае керований натовп міквідував індивідуальність... Принцип конфмікту - зіткнення могіки та алогізму є типовим режисерським ходом автора» [1, с. 325-326].

Можна припустити, що скиадні філософські підтексти у творчості художника спровокувала низка факторів: Аитячі спогаАи про виселення з теренів Польщі та пере-

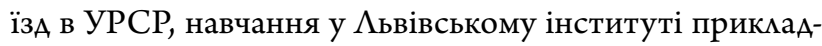
ного і декоративного мистецтва (закінчив 1965 року). Також на професійне мислення позитивно вплинули митці-наставники Р. Семьський, К. Звіринський, А. Аовбошинський, В. Манастирський, І. Скобало. Творчість мьвів'янина українські науковці часто розглядають у порівнянні з роботами близьких Арузів - О. Мінька та 3. ФАінти, хоча на Ауховно-стилістичний вектор розвитку також позитивно впливали А. Бокотей, І. Марчук, $\Lambda$. Пушкаш, О. Мінько, Б. Галицький, П. Маркович [2, с. 3]. Роботи $\Lambda$. МедвіАя часто відображають не тільки власний «Всесвіт з чітко обраною філософією життя», а й алегоричність образів, що є гострою мистецькою рефлексією на тогочасні всеукраїнські мистецькі процеси.

Малярство $\Lambda$. МеАвіАя, преАставника иьвівської мистецької школи Аругої половини ХХ століття, стало об'єктом мистецької уваги й критики ще віА раннього пеpiоду творчості. Починаючи віА 1960 -х років, в роботах художника зароджуються та визрівають експресивні тенАенції. Експерсіоністичним за манерою вважаємо картон «ХАопчики акробати» (1962) зі збірки Т. Салиги. 1960-ті роки у творчості $\Lambda$. МеАвіАя досліАжувала $\Lambda$. Во-

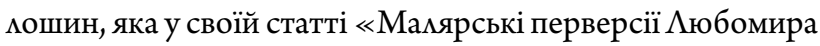
МеАвіАя» вАало характеризує цей періоА як експресивногротесковий: «МолоАий хуАожник оперує піАкреслено умовними формами - спрощеним рисунком, нарочито грубими гротескними контурами, на які неспокійно кинуті умовно кольорові плями. Експресія, епатуючи перверсійність образної мови, АовеАена тут до сюрреалістичного звучання. Водночас, у творах цих прочитуються уроки таких майстрів європейського малярства, як Брак, Міро, Шагал, Сальвадор Аалі, - всі вони у студентські роки фасцинували творчу уяву $\Lambda$. МеАвіАя так само, як і Аивовижно настроєва сюрреацістична поетика мітературних творів Франца Кафки. САіА, між іншим, зазначити, що ця рання творчість $\Lambda$. МеАвіАя була своєріАним бунтом яскраво обАарованої мистецької особистості проти усталених вже вартостей очоленої Р. Семьським мьвівської живописної школи 60-х років, де акцентувалися, насампереА, урочисті і віАсторонені віА реалій насущного життя Аекоративно-колористичні якості малярства» [3, с. 344].

Особистість художника глибоко інтелектуальна, що відображається у творчих інтенціях митця. У творчості $\Lambda$. МеАвіАя 1980-х років простежується абсураність тогочасної системи. Помотна вражають трактуванням композиційних та колористичних вирішень, гіперболізацією люАських тіл і почуттів, глибоким психологізмом, склаА-

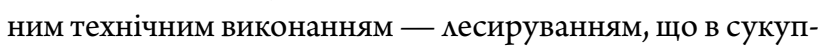
ності створюють стиль художника.

Аналізуючи творчу Аіяльність митця початку 1980-х років, мистецтвознавець М. Мусій акцентує увагу: «.... МеАвіАь свою виставкову Аіяльність провадив спільно з О. Міньком та З. ФАінтою (практика формування таких неофіційних “угрупувань” за інтересами властива мистецькому середовищу не мише $\Lambda$ ьвова, а й інших значних культурних осереАків) ... 3 Аругої половини 1980-х рр. мистецтвознавці фіксують філософсько-концептуалістські нюанси у процесі художнього творення» [4, с. 104]. За словами Г. Островського, мьвівський художник $\Lambda$. МедвіАь: «тяжіє Ао зовнішнього заспокоєного, аме, по суті, внутрішнього напруженого та експресивного, навіть гостро конфміктного мистецтва» [5, с. 208].

Амя Аьвівського митця період 1980 -х років надзвичайно пміАний, світ побачили цикли «Розточчя» (19862007), «Яворівщина» (1988-91), «АюАина і земля» (1986-1988), «Інтер'єри» (1984-1991), «Евакуації» (1986-1996), «Емігранти» (1982-1990), де постають технічні та концептуальні елементи, притаманні його авторській манері. У часовій послідовності найперше, Ае з'являються експресивні інтенції, - серія «Емігранти» (1982-1990). Емігранти галицькі - це експресивно намальовані постаті цюдей, які в свойй Аинаміці спонукають Ао розАумів про сенс життя. Як загаАано в інтерв'ю 
М. Білан: «Ми хочемо проникнути за зовнішню оболонку речей, Аістатися їх внутрішньої сутності й одночасно пізнати ті зв'язки, які зробили їх саме такими, а не інакшими» $[6$, с. 97$]$.

Особливу увагу привертає цикл «Евакуації» (19841991), Ао цього періоду належать «Евакуація Р. ГАаяяка» (1984), «Евакуація - Бамет» (1984), «Евакуація Мішки» (1989), «Евакуація Г. Островського» (1986). СереА серії виАіляється склаАними контроверсійними почуттями саме «Евакуація Г. Островського» (1986). Полотно вертикальне, за основу взято монохромну чорно-білу кольорову палітру з червоними колористичними акцентами, що якнайкраще переАають фігури мюдей у русі, створюють ілюзію Аинаміки. Можна зазначити, що розташування фігур, ракурси «згори», Ае навмисно розмито і неАомальовано частини тік, є піАсилювальними елементами в роботі. На переАньому плані, сереА юрби жіночих і чоловічих постатей, привертає увагу образ жінки, яка сереА цього хаосу з мюбов'ю пригортає Ао себе маленьку Аитину. Всі елементи композиції, а саме - сірий і червоний фон та Аинамічно-експресивні фігури - підпорядковуються оАній траєкторії «по колу», посилюють тривожний настрій, гармонійно розкривають тематику «евакуацій» АюАських особистостей не тільки на фізичному, а й на психологічному та духовному рівнях. Червоний колір, що заповнює простір між фігурами, Аодає тривожності, напруженості атмосфери, і є вАалим поєАнавчим елементом між заднім пианом і фігурами. Особливу увагу $\Lambda$. МеАвіАь придікив деформації тіл, які вражають своєю графічністю, конструктивною побудовою та ракурсами, загострюють загальну атмосферу, Аоводячи ї̈ до піку експресивності. Уся складність обраної тематики показана на прикладі юрби, яка мчить наосліп у невідомому напрямку. Вражає повне розмивання рис, віАсутність Аеталізації нюАських обмич, які ніби загубилися сереА цього хаосу. АюАи є безмикими створіннями, кволими, худими. У роботі «Евакуація Г. Островського» (1986) художник майстерно ретранслюе експресивне світовідчуття і власну живописну систему. За спостереженнями Г. Островського, у цей період художник «...тяжіє до експресіоністичних течій у мистецтві, сюрреалізму, який живився враженням віА прози Кафки, живопису Кіріко та М. Шагама ... » [7, с. 111].

У Аругій половині 1980-х років відбувається трансформація стилю художника в більш експресивний бік, основна увага концентрується на пластиці форми, колористиці, деформації об’єкта та ритмі. Аьвівський митець майстер нестандартних образних вирішень, контрастних і протилежних співвіАношень мюАей-персонажів, які випромінюють Аобро і зло, високе й нице, красиве і потворне, розум і хворобу, екзальтацію та спустошення, безневинне та гріховне, роздвоєння особистості на рівні духовного, фізичного та глобального поняття Всесвіту. Своєрідна графічно-живописна мова художника часто спонукає Ао розАумів про Ауховне та мирське, про гру піАсвіАомості та свіАомості реципієнта, пошук піАтекстів і смислів, які в самій назві роботи вже провокують на Аіалог. Серії робіт чітко стосуються певних мистецьких завАань, запитань, прозрінь, висновків, на які сміливо звертає нашу увагу $\Lambda$. МедвіАь. Про співзвучність з духом часу та мистецькими цінностями, які ретранслюють у своїх роботах В. Патик, М. Кристопчук, А. МеАвіАь, Я. Мотика, І. Остафійчук, М. І ку, Є. Безніско, І. Крислач, А. Крвавич, роздумує у своїй статті «Живописці зі АосліАник у загальних рисах аналізує творчість митців, та у випаАку А. МеАвіАя щоАо його робіт 1980-х, констатує: «Автор експресивно свіжий, емоційно напружений, фарби у $\Lambda$. МедвеАя - аля розаумів» $[8$, с. 73]. Картини $\Lambda$. МеАвіАя - це сукупність пережитих емоцій чи поАій, які пробудили внутрішній імпульс, що трансформувався у певну тематику, композицію та форму, гармонійно поєАнався з іАеєю, концепцією, технічними елементами, які створюють завершений образ.

Митець рухається у суголоссі з переАовими тенАенціями того часу, вдосконалює та розробцяє наступні цикли. Кінець 1980-х позначений серіями «Розточчя» (1986-2014), «Яворівщина» (1988-1991), «Аюдина і земля» (1986-1988). С АіА звернути увагу на цикм «Розточчя», який є зіставленням мюАської особистості з природою Яворівщини. Мотиви циклу: «Нешлюбні Аочки» (1989), «Опустілий пляж» (1987), «Оголена» (1988), «Минаючи Страдч» (1988), «Невістка $1 \gg(1989)$, «Невістка $2 \gg(1989)$, «САіпий дощ», «САіпий дощ 2». Загамом серія робіт розрухує контроверсійні почуття, з одного боку, радісні, з іншого - виникають емоції страху, загрози переА незбагненним. Сам художник так пояснює свій задум: «... Тому Розточчя аля мене більше знак, символ, образ, ніж конфігурація земної кори десь посередині континенту, назва якого - Європа» [9, с. 119]. Митець розробив власний піАхіА Ао організації картинного простору, Ае кожен елемент, фактура, фігура чи об'єкт - на своєму місці, разом утворюють життєстверАний образ.

У серії «Розточчя» (1986-2014) своїм філософським задумом привертає увагу картина «Нешлюбні дочки» (1989). У композиційній структурі центральне місце віАвеАено оголеній постаті жінки, що присіла, її голова спирається на міву руку. Задумливості обличчю додають заплющені очі, тоді як у правій руці жінка тримає щось схоже на біку Араперію. Позаду неї стоїть невелика постать іншої жінки в хустині, яка може бути візуамізацією минулих подій, спогаАів, уяви. ОбиАва образи немовби застрягли на безкрайому полі, Ае в Аалечині видніються мише лінії електромереж. Можна сприймати роботу по-різному як постать матері і дочки, народженої не в шлюбі, як постаті матерів, оАна $з$ яких оголена, що може символізувати спокуту, провину. Митцеві вАалося поєАнати інтригу з гострою суспільною проблематикою, складними Ауховними переживаннями та внутрішньою боротьбою. У роботі переплетені смуток і напружена атмосфера, сугестивна виразність образів і повчання, внутрішня порожнеча і наповненість. ЗаАній план - це поле, що зачаровує Аовершеністю мазків, Ае трактування трави, ії мегкі фактури тільки сприяють концентрації уваги реципієнта на центральних образах. У цьому полотні $\Lambda$. МеАвіАь майстерно володіє виражальними засобами: дрібна та багата на деталі 
фактура, монументальна пмяма і мегка мінія, детамізований рисунок і складна композиційна структура. Відтак, гостра проблематика в суспільстві стає ареною Аля експериментів з ідеєю, формою, композицією та колористикою.

Проаналізувавши декілька полотен $\Lambda$. МеАвіАя 1980-х років, створених у власній авторській манері, можемо стверАжувати, що це унікацьний мистецький шлях з експресивними елементами у творчості, які сьогодні художник і Аалі вдосконалює. Як зазначає автор: «Мистецтво - це засіб комунікації, воно $є$ певним знаком, певним сигналом. Мистецтво $€$ цінним тим, що воно говорить про те, що люАська мова не зАатна оформити. Мистецтво також говорить мовчки, за порогом мовчання воно промовмяє. За Аопомогою фарб, за Аопомогою пензця я можу щось сповістити і я це роблю» [10].

У роботах художник навмисно порушує болісні теми, піАсвіАомо викликаючи у глядача склаАні асоціативні зв'язки, які спонукають до власних висновків і міркувань, Ао переосмислення набутого Аосвіду, вагомих змін на Ауховному рівні. За словами $\Lambda$. МедвіАя, визначення мистецтва за часів панування соцреалізму звучить так: «За часів загратовано-казенної раАянської системи мистецтво було анклавом, затокою, фйордом, куАи ти зміг запливти і отримати можливість - як Аивно це не звучало 6 - звершитися віА початку до кінця, уцікіти, зберегти свою особистість» $[9$, с. 12]. Живописні полотна $\Lambda$. Медвідя займають визначне місце у мьвівському та загальноукраїнському мистецькому процесі, аАже, незважаючи на численні перепони, їм вАалося втримати українське мистецтво на високому європейському рівні.

Характерний Аух містичного експресіонізму присутній у творчості Мирослава Ягоди. Він - багатогранна та надзвичайно експресивна творча особистість і за темпераментом, і за способом образно-ідейного наповнення полотна. Професійну мистецьку освіту зАобув в Українському поліграфічному інституті (сьогодні - Українська академія друкарства), який завершив 1986 року. Мирослав Ягода - не тільки художник, а й поет, сценограф і перформер, бкагодійник (у час війни на Сході України весь гонорар за продані з експозиції роботи переАав на потреби армії). Його прямолінійне мислення, внутрішня потреба малювати та природна обдарованість відобразилися у характері нервової, навіть фантастично-демонічної експресивної мови. Безстрашність і емоційність характеру митця позначається і на тонально-колористичному наповненні картини, Ае насичені яскраві барви піАсилюють певний мистецький образ. У його полотнах переплітаються амегоричні, потойбічні, містичні образи-виАіння, часто спровоковані психічною хворобою. Аля мене постать М. ЯгоАи - це «Аьвівський Мунк», де експресія барви, Аінії, плями, композиційної структури, тепло-хомодності і навіть назви роботи переплетені настільки вмі$\Lambda$, що створюють ірреальний, метафорично-образний світ, де емоція довеАена до абсолюту, межує з надривом. Його живописний Аоробок можна зарахувати то сучасної течії неоекспресіонізму, де свідомість настільки тісно пов'язана з підсвіАомістю, що вони стають одним цілим.
Композиції полотен часто розімкнуті, фон, назва і навіть образи змиваються в єАину картину мистецького буття. Роботи М. ЯгоАИ — це протест проти несправеАливості буття, вираження певної незгоди, «крик» на ту неправАу та непорозуміння, що є в суспільстві. Живопис аля митця - своєріАний «плацАарм», Ае він зміг реалізувати свій творчий потенціал, «внутрішній емоційний порив».

На віАміну віА інших творчих особистостей $ь в і в-$ ського мистецького сереАовища, Аля яких основним Ажерелом натхнення залишалася природа, М. Ягода полюбляв усамітнитися в майстерні наодинці з власними Аумками та візіями. Важливу роль у творчому зростанні художника віАіграло оточення, Ао якого входили абсолютно різні за своїм світосприйняттям і матеріацьним статусом люАи. Позитивно згаАують про митця його близькі Арузі, сереА яких Петро Старух, Влодко Кауфман, Римма Гуп, Петро Гуменюк, Андрій СагайАаковський, Оля Стеблюк, Михайло Красник. 3 розповідей друзів Аізнаємося цікавий факт: митець часто малював при світлі синьої мампи, що їх часто використовують в операційних, що теж впливає на характер сприйняття світу та колірних співвідношень на палітрі. Пкастичній мові автора присвятив статтю «Творчість Мирослава Ягоди» О. РуАенко, який наголошує: «НаАзвичайна важливість кольору, який Азвенить часом нотою надривного колористичного нюансу з-поза символів зрозумілих і незрозумілих, ілюзорних та ілюзіоністичних виАінь автора; Ае колір стає символом пульсуючого життя, сереА інертного, розщепленого мороку знаків тла-простору картини» [11, с. 57].

Найбільша кількість робіт автора була представлена на посмертній виставці «Ягода Мирослав» (2019), що віАбулася у палаці Аозинського. Крім живопису, були преАставлені також графічні роботи, які $є$ першоджерелом Аля експресивного живописного ракурсу митця. Чорнобілі графічні постаті, обличчя майстерно переплітаються з багатьма мініями та плямами, викликають відчуття смерті, Аволикості життя. Живопис $є$ органічним продовженням графіки, але набагато складнішим, саме він вражає метафоричним наповненням і мистецькими вартостями. Перевага чорних фонів, демонічність і фантазійність образів нагадують нам творчість німецького неоекспресіоніста Г. Базеліца, експресію мазка в роботах Ф. Бекона, Ж. Руо з його чорною мінією, хоча творчість мьвів'янина суттєво віАрізняється. На розгляА публіки преАставлено Авоповерхову експозицію «Мирослав ЯгоАа. Чи я тут чи я там». Серед репрезентованих полотен до цього періоду належать «Автопортрет» (1992), «Вов. Кулака» (1989), «Чорна мадонна чи крик півня» (1989), «Пісня щура» (1989), «Кожен з нас є буханкою хліба з віАрізаним окрайцем» (1989). Тематичною основою картини $є$ міфо-

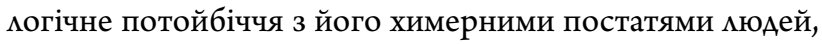
богів, істот, Аемонів-створінь, які намагаються затягнути у свій світ мороку. Образи контроверсійні, психологічно скмаАні, глибоко асоціативні, Аля когось можуть бути незрозумілими чи навіть потворними. Його геніальність екстраординарна, роботи приваблюють своїм містицизмом, загаАковістю персонажів і оАвічністю боротьби Авох 
сим буття. Безперечно, саме така тематика робіт пов'язана 3 його хворобою та особливим поглядом на світ. Розкута живописна манера, рельєфність барви на полотні демонструють певну частинку душі та ідею, яку вклав автор.

У статті-спомині про художника аналізує його творчість 1980-х - 1990-х досліАник і товариш Т. Возняк, акцентуючи увагу на багатьох аспектах, зокрема, на психомогічному портреті, побуті, мистецтвознавчому анацізі творів, сереА яких зацікавили слова про процес і внутрішній стан, у якому творив митець. За спогадами науковця: «Він не виписував полотна. Не бавився з ними роками, як правило, це був напаА творчого шалу, перемішаної з раАістю чи болем мюті. Аосить мише кинути оком на розмитість його письма, щоб це побачити. Часто це застигла у фарбі мить ... Отож, як на мене, Аля Мирослава суть творчості помягала у самому акті запитування, витягування віАповіАі, змушення до віАповіАі - і то не нас, смертних, а Когось Іншого» [12, с. 17-18].

Оригінальним підходом позначена робота «Палаючий образ» (1988). СереА полотен, преАставлених на виставці, вона виділяється активним поєАнанням Авох основних барв - жовтої та синьої. Композиційна структура полотна горизонтальна, кольорова палітра вражає позитивною енергією порівняно з іншими, віАверто Аемонічними образами, які виринають з пітьми. Центрахьним елементом картини $є$ сикует-образ півфігури з піднятою вгору рукою, постать розташована на синьому тлі, що нагадує небо. За характером трактування за основу образу взято мокальний жовтогарячий колір, що на контрасті з холоАною синьою барвою справді ніби «палає», «світиться». Основна текстура, фактура та рельєфність міній живописної мови зосереАжені саме на обличчі та тілі загадкового персонажа. Якщо провести паралемь з біблійною тематикою, Ае Господь звернувся Ао Мойсея у вигляАі охопленого вогнем тернового куща, можливо, в інтерпретації та баченні М. ЯгоАи так і вигляАає божественний образ. Значну увагу приділено детамям, таким, як мінї, крапки, цятки, які, на перший погляА, можуть зАатися несуттєвими, але насправАі відіграють важливу роль. Робота вирізняється також певною «мінімалістичністю» живописних засобів, проте не $\epsilon$ віА цього менш експресивною. Чорний контур обрамлює роботу зі всіх боків, крім низу, ніби піАсумовуючи та замикаючи вогняний сикует. Отже, полотно «Палаючий образ» (1988) експресивне з огляду на активну взаємодоповнювальну колористику, експресивну техніку виконання, глибинну іАею та увагу Ао деталей.

Інший образно-пластичний устрій має глибоко фімософська та водночас багата на асоціації за своїм значенням робота «Кожен з нас $є$ буханкою хміба з вілрізаним окрайцем» (1989). Основу горизонтальної композиції складає буханець хліба, окраєць якого зміва віАтяв меч. Якщо подивитися на обидва шматки, можна розпізнати в них гримаси з мюАських облич, які нагаАують маски племен Африки. Представлені обличчя хліба та окрайця оАухотворені, наАілені АюАськими рисами, емоціями, стражАаннями. Зокрема, у роботі присутня персоніфікація неживих преАметів, наАання їм мюАських рис і емоцій, що наштовхує на неординарний погляА, багаті асоціативні зв'язки. НаприклаА, проведення паралелі між мюдиною та хлібом з віАрізаним окрайцем викликає асоціацію $з$ життям, що видозмінює предмет чи живу істоту. По-іншому це можна трактувати як образ власних душевних ран, запитань, вагань, внутрішніх суперечностей. Виразність вигаданого образу Аосягається за Аопомогою експресивної манери виконання, чергування хаотичних і чітко спрямованих мазків, що в сукупності створюють ціяісний графічно-експресивно-живописний образ. Важливу роль у роботі віАіграють чорні тіні та фон, які посилюють контраст між світлом і темрявою, впливають на їхній баланс. Говорити знаками, символами, експресією мазків і барви, метафоричними назвами $є$ характерним прийомом, який використовував у своєму арсеналі Аьвівський художник.

У Аоробку художника 1980-х років експресіонізм розвинуто та реалізовано в низці полотен, у яких вирують АИнаміка барви, Аемонічний та потойбічний настрій, загаАковість темряви. За тверАженням досліАника М. РУАенко: «НаАзвичайна важливість кольору, який Азвенить часом нотою наАривного колористичного нюансу з-поза символів зрозумілих і не зрозумілих, ілюзорних та ілюзіоністичних видінь автора; де колір стає символом пульсуючого життя, сереА інертного, розщепленого мороку знаків тлапростору картини. В невимушеності накладання фарб праця розуму. Аумати, розуміти, це Аля митця означає творити. Через творчість він пізнає світ, а світ його. Праця розуму - головний елемент художньої кухні Мирослава Ягоди. Без мислення картина позбавлена глибини, прісна та мертва» [14]. Його творчий шлях був тернистим і складним, що можна порівняти 3 «дозріванням ягоди», яка, налившись соком, швиАко згоріла піА променями активного сонця, залишивши справді химерну та унікальну експресивну спадщину аля сучасного мистецтва $\Lambda$ ьвова.

На окрему увагу сереА мьвівських митців заслуговує художник старшого покоління М. Безпальків. Митець професійну освіту зАобув у Аьвівському інституті Аекоративного і прикладного мистецтва у 1963-1968 роках, Ае викладачами з фаху були видатні особистості К. Звіринський, Р. Сельський, В. Черкасов, А. Аовбошинський, В. Манастирський. Широкий мазок у поєАнанні з мінією контуру, експресивне моделювання форми, деталізація та узагальнені площини притаманні Аля мистецького доробку М. Безпальківа. Його полотна багаті на українську тематику, засновані на переосмисленні натури. Живопис характеризується яскравою колористикою, часто полотна відображають реальне життя чи міфологічні сюжети. У катамозі «Михайло Безпальків» (1999) І. ГолоА викладає свої спостереження: «Амплітуда образно-тематичних коливань величезна і нетривка піА стусанами суспільно-політичних змін: віА напрочуд міричних, дещо сумних, пейзажів Карпат, сільських БогороАиць, муАро-лукавих броАівських АяАьків Ао пикатих мюАинопотвор, якими “ознаменовано” затяжний перехіАний періоА в історії України i, нарешті, до оптимістичних картин-поглядів у майбутнє незалежного ріАного краю» $[15$, с. 1]. У каталозі преАставлені роботи віА 1970-х по 1990-ті, сереА них і роботи 1980-х рр.: «За парканом» 
(1982), «Зимовий спокій» (1985), «Засніжений міс» (1986), «Край села» (1987), «Виховання (Аіва частина триптиху “ЖиттєАавці”)» (1988). А^я художника період 1980-х позначився зміною авторської манери в бік експресивності. Ао робіт цього періоду також належать «Автопортрет» (1981), «Букет» (1981), «SOS» (1985), «Матері» (1985), «Робітник» (1985), «Хімічна тривога» (1985), «Семянка» (1985), «ОАинокий Авірник» (1985), «Н $\mathrm{O} \gg(1986)$, «Триптих. Що не Аень, то веселіше життя» (1986), «Перебудова» (1987), «Благословіння батьків (1987), «В поме» (1987), «БкуАний син» (1988), «Ауми мої, Ауми мої» (1988), «Той, що прикурює» (1988), «Чорнобильська мадонна» (1988), «Жінка зі свічкою» (1988), «Мандрівні художники» (1989). Аля робіт цього періоду характерна побутова тематика, зображення простих АюАей та їхнього життя, тоАі як «Чорнобильська мадонна (1988), «Перебудова» (1987) є реакцією на поАіï, які віАбуваються в суспільстві, хвилюють тонкі струни душі автора. У цьому контексті доречно навести цитату I. Ткачук, яка АосліАжує взаємовпливи між митцем, полотном і реципієнтом: «Аля творця актуальним $є$ феномен існування його у віАмінних віА нього самого чинниках. А з іншої позиції - кожна мюАина, предмети, твори мистецтва містять віАбитки чиїхось переживань, Аумок, ціннісних орієнтацій, які й складають феномен мюАського інобуття, такої форми існування мюдини, коли вона залишає сліА в інших носіях» [16, с. 143]. Характерною ознакою творчості М. Безпальківа 1980-х років $є$ використання власних глибоких переживань, набутого досвіду, Аумок, які виливаються на полотно у вигляді активних кольорових плям, що в поєАнанні з фактурністю та обраним сюжетом створюють експресивні композиційні структури.

Експресивними нотками багата робота «Благословіння батьків» (1987), Ае постаті чоловіка і жінки майстерно поєАнані з фоном. Композицію можна поділити на Ава основні плани, Ае на передньому зображені постаті батьків, а за ними простягається родюча українська земля. Образ вусатого батька нагадує постать вільного козака, патріота своєї батьківщини. Чоловік піАняв праву руку, тоді як міва на рушнику тримає хлібину. Жінка-українка намальована в народному одязі, на голові хустина, руки схрещені на таміï, піА правою рукою видніється книга. Постаті батьків зображені на чорноземі, українській землі, символі родючості та Аостатку. Полотно вражає майстерністю авторської мови, що виражається у фактурному фоні, який викликає асоціації 3 Аимом і водночас створює відчуття світіння фігур. Етнічна складова відіграє важливу роль у творчості художника, який не тільки оспівує, співпереживає та опрацьовує українську тематику, він $є$ активним учасником естетичного емоційного пориву, що віАображається на полотні. Загалом картина сприймається цікісно за рахунок обраної колористики. У цьому творі художникові вАалося поєАнати виразні образи українців з експресивною фактурою та мазком.

Наштовхує на внутрішні роздуми картина «SOS» (1985), яка своїм сюжетом і психологічними підтекстами апелює до класиків - I. Босха «Човен дурнів» (1500) та Т. Жеріко «Пиіт меАузи» (1819). Композиція буду- ється на контрасті захмареного неба, спокійного блакитного моря та човна, наповненого мюАськими образами. Характер стилізації багатьох фігур, фактура хвиль і динаміка сюжету наштовхує на думку про неминучість загибемі судна з усіма його пасажирами. Картина відображає Аві протилежні стихії - силу природи та мюдину. 3 іншого боку, сюжет можна трактувати як реальне відчуття та стан суспільства 1980-х, яке в прямому сенсі «тоне» піА гнітом соцреалізму. Наповненість живописного полотна сформована на зіставленні світлого фону та темного за тональним співвіАношенням корабля. Інтенсивна жовта, помаранчево-червона барви на контрасті з блакитними мазками тільки посилює відчуття експресії. Окремої уваги заслуговує невимушена мегкість і віртуозність у трактуванні динамічних поз, багатий спектр емоцій. На кораблі зображено момент, коли переважає всеохоплююча паніка, страх і віАчай. Обличчя «пасажирів» написані мегко, на одному поАиху, з іншого боку - майстерно віАображають широкий спектр емоцій. Загалом художникові вАалося інтегрувати класичний сюжет піА власну філософську систему, інтерпретувати та втілити ту тематику, що насправАі віАображає внутрішню потребу та прагнення автора поділитися своїми думками й переживаннями із суспільством.

Роботи М. Безпальківа є зображення всієї епохи, яка сформувалася в період політичних і духовних утисків. За словами самого художника: «Я не можу мамювати те, що красиве, а те, що мені подобається» [17]. Творчість мьвівського художника $є$ прикладом вічної боротьби талановитої особистості, де роботи - це рефлексії на виклики життя у вигляді образів, філософських піАтекстів, композиційних структур.

Висновки. Отже, упродовж 1980-х років у живописних полотнах мьвівських митців зростає експресіоністична склаАова. Картини втілюють не тільки потужний емоційний порив, а й скмадні філософські, глибоко національні та власні Ауховні розАуми, які в цей періоА переживають художники.

У процесі досліАження вдалося проаналізувавши вибрані живописні твори та творчість 1980-х років трьох Аіаметрально протилежних митців: $\Lambda$. МеАвіАя, М. Ягоди, М. Безпальківа, об'єАнавчим моментом сереА яких $є$ наявність виразних експресіоністичних тенденцій. СліА зазначити, що українські мотиви, побутова та пейзажна тематики посіАають значне місце у тематичному Аіапазоні обраних митців. СереА характерних рис, притаманних Аля творчості мьвів'ян: стилістична виразність, насиченість барви, фактурність, виважена композиційна побудова. Станкові полотна це, безперечно, індивіАуальні шляхи в мистецтві, об'єАнавчим елементом яких $є$ наявність експресивних тенденцій, виражених різною мірою. НаприклаА, у $\Lambda$. МедвіАя вони зароАжуються та виражаються через обмежену кольорову палітру, деформацію мюАських тік, несподівані ракурси, гротеск, перспективу, тоді як у М. Ягоди вагому роль відіграє чорний колір-пітьма, експресивні мазки яскравих барв, складний фімософсько-демонічний підтекст. У роботах М. Безпальківа переважає фактура, зосереАженість на емоційній складовій, присутні узагальнені площини, збагачені численними технічними прийомами. Так чи інакше, експресіоністичні тенденції 
різною мірою виражені на полотнах 1980-х за допомогою різних образотворчих прийомів.

Саме тому можна стверАжувати, що в період 1980-х років творчість $\Lambda$. МеАвіАя, М. ЯгоАИ, М. Безпальківа містить експресивний вектор. Художники віАроджують не тільки національні риси в мистецтві, а й професійно зростають у власних коАах, Ае гармонійно поєАналися регіональні та інтернаціональні риси.

\section{$\Lambda$ ітература}

1. Петрова О. Мистецтвознавчі рефлексії: Історія, теорія та критика образотворчого мистецтва 70-х років XX ст. - початку XXI ст.: 3б. ст. Київ: Академія, 2004. С. 322-328.

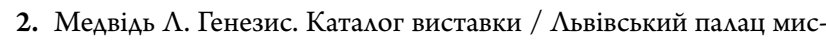
тецтв; $\Lambda$ ьівська національна галерея мистецтв ім. Б. Возницького. Аьвів: [б. в.], 2016. 35 с.

3. Волошин $\Lambda$. Мамярські перверсії Аюбомира МеАвіАя // Вісник

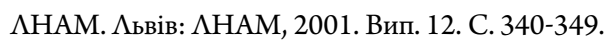

4. Мусій М. Мистецтвознавчі інтерпретації творчості Аюбомира МеАвіАя у періодичних виланнях 1960-2000рр. // Наукові записки. Теорія та історія кумьтури. Т. 49. С. 102-107. URL: http:// ekmair.ukma.edu.ua/bitstream/handle/123456789/7691/Musiy_ Mystetstvoznavchi_interpretatsiyi_tvorchosti.pdf (Аата звернення: 8.03.2020).

5. Островський Г. Полотна трьох // Вітчизна. 1983. № 9. С. 208.

6. І вірні живопису. (Інтерв'ю Майї Бікан з художниками $\Lambda$. МеАвідьом, О. Міньком та 3. ФАінтою) // Жовтень. 1982. № 4 (450). C. 96-98.

7. Островський Г. Автопортрет митця з варіаціями. Жовтень. 1984. № 9 (479). С. 110-115.

8. Островский Г. Живописцы из Аьвова. Москва: Искусство, 1987. № 5. С. 23-29.

9. Медвідь А. Ремінісценціі. Аьвів: Компанія Гердан, 2010. 119 с. 10. Інтерв'ю із Аюбомирем МеавіАем. Аьвів, 20 жовтня 2020 року. (Приватний архів Н. Братюк).

11. Руденко О. Творчість Мирослава Ягоди / / Образотворче мистецтво. 2018. Ч. 2. С. 56-58.

12. Возняк Т. Мирослав Ягода «Соняшники Ван Гога треба показувати разом з його вухом» // Незалежний культурологічний часопис « $\ddot{\mathrm{I}} \gg .2018$. Число 89. URL: http://www.ji.lviv.ua/n89texts/N89Yagoda.htm (Аата звернення: 2.06.2020).

13. Бондаренко А. Мирослав Ягода: Я створив свій світ і я щасливий. 21 серпня 2014. URL: https://varianty.lviv.ua/21463-myroslavyahoda-ya-stvoryv-svii-svit-i-ya-shchaslyvyi (Аата звернення: 3.06.2020).

14. Руденко М. Мирослав Ягода. Аата оновмення: 24.08.2014. URL: http://excess.online/2014/08/\%D0\%BE\%D0\%BB\%D0\%5\%D0\%B3\%D1\%80\%D1\%83\%D0\%B4\%D0\%B5\%D0\%BD\%D0\%BA\%D0\%BE\%D0\%BC-\%D1\%8F\%D0\%B3\%D0\%BE\%D0\%B4 \%D0\%B0/ (Аата звернення: 3.06.2020).

15. Михайло Безпальків: альбом. Аьвів: [б. в.], 1999. 28 с.

16. Ткачук I. Принцип зворотного зв'язку в системі «Митець живописний твір - реципієнт» // Традиції та новітні технології у розвитку сучасного мистецтва. Збірн. матеріалів IV-ї Всеукр. науково-практ. конференції. Черкаси: [б. в.] , 2016. № 3. С. 143-146. 17. Ярема Г. Я завжАи стильно одягався, бо сам собі шив // Високий Замок. Аата оновлення: 23.03.2019. URL: https://wz.lviv.ua/ interview/387089-ya-zavzhdy-stylno-odiahavsia-bo-sam-sobi-shyv (Аата звернення: 12.06.2020).

18. Михаймо Безпальків: альбом. Аьвів: [б. в.], 2012.

\section{References}

1. Petrova, O. (2004). Mystetstvoznavchi refleksii: Istoriia, teoriia ta krytyka obrazotvorchoho mystetstva 70-kh rokiv XX st. - pochatku XXI st [Art reflections: History, theory and critique of fine arts of the 1970 s and early $21^{\text {st }}$ century]. Akademiia.

2. Medvid, L. (2016). Henezys. Kataloh vystavky [Genesis. Exhibition catalog] (n. p.).

3. Voloshyn, L. (2001). Maliarski perversii Lubomyra Medvidia [Painting perversions of Lubomyr Medvid], Visnyk LNAM, 12.

4. Musii, M. (2006). Mystetstvoznavchi interpretatsii tvorchosti Lubomyra Medvidia u periodychnykh vydanniakh 1960$2000 \mathrm{rr}$ [Artistic interpretations of Lubomyr Medvid's work in periodicals of 1960-2000.], Naukovi zapysky. Teoriia ta istoriia kultury, 49. http://ekmair.ukma.edu.ua/bitstream/handle/123456789/7691/ Musiy_Mystetstvoznavchi_interpretatsiyi_tvorchosti.pdf

5. Ostrovskyi, H. (1983). Polotna trokh [Canvases of three], Vitchyzna, 9, 208.

6. I virni zhyvopysu. (Interviu Maii Bilan z khudozhnykamy L. Medvidom, O. Minkom ta Z. Flinta) (1982). [And true to painting. (Interview of Maya Bilan with artists L. Medvid, O. Minko and Z. Flinta], Zhovten, 4(450), 96-98.

7. Ostrovskyi, H. (1984). Avtoportret myttsia z variatsiiamy [Selfportrait of the artist with variations], Zhovten, 9(479), 110-115.

8. Ostrovskyi, H. (1987). Zhyvopystsy yz Lvova [Painters from Lviv], Iskusstvo, 5, 23-29.

9. Medvid, L. (2010). Reministsentsii [Reminiscences]. Kompaniia Gerdan.

10. Interviu iz Lubomyrem Medvidem (2020). [Interview with Lubomyr Medvid]. Pryvatnyi arkhiv N. Bratiuk.

11. Rudenko, O. (2018). Tvorchist Myroslava Yahody [Works by Myroslav Yagoda], Obrazotvorche mystetstvo, 2, 56-58.

12. Vozniak, T. (2018). Myroslav Yahoda "Soniashnyky Van Hoha treba pokazuvaty razom z yoho vukhom") [Myroslav Yagoda "Van Gogh's sunflowers should be shown together with his ear"], Nezalezhnyi kulturolohichnyi chasopys "Yi", 89. http://www.ji.lviv.ua/n89texts/N89Yagoda.htm

13. Bondarenko, A. (2014). Myroslav Yahoda: Ya stvoryv svii svit i ya shchaslyvyi [Myroslav Yagoda: I created my world and I am happy]. https://varianty.lviv.ua/21463-myroslav-yahoda-ya-stvoryvsvii-svit-i-ya-shchaslyvyi

14. Rudenko, M. (2014). Myroslav Yahoda [Myroslav Yagoda]. http:// excess.online/2014/08/\%D0\%BE\%D0\%BB\%D0\%B5\%D0\%B3-\% D1\%80\%D1\%83\%D0\%B4\%D0\%B5 \%D0\%BD\%D0\%BA\%D0\%BE\%D0\%BC-\%D1\%8F\%D0\%B3\%D0\%BE\%D0\%B4 \%D0\%B0/

15. Mykhailo Bezpalkiv. Albom (1999). [Mykhailo Bezpalkiv. Album]. (n. p.).

16. Tkachuk, I. (2016). Pryntsyp zvorotnoho zviazku v systemi "Mytets - zhyvopysnyi tvir — retsypiient" [The principle of feedback in the system "Artist — painting — recipient"]. In Zbirn. materialiv IV-yi Vseukr. naukovo-prakt. konferentsii. (n. p.). No. 3.

17. Iarema, H. (2019). Ya zavzhdy stylno odiahavsia, bo sam sobi shyv 
19. МедвіАь $\Lambda$. ПараА парабол. Альбом. Аьвів: Колір ПРО, 2015. $107 \mathrm{c}$.

20. Островський Г. Аюбомир МедвіАь, Олег Мінько, Зеновій Фмінта. Каталог. Аьвів: ОблполіграфвиАав, 1981.22 с.

21. Аюбомир МеАвиАь, Олег Минько, Зеновий Фминта. Живопись. Каталог выставки; $\Lambda$ ьвовская орг. СХ УССР / авт. вступ. ст. и сост. Г. Островский. Москва: Советский художник, 1986. С. 3.

22. Аюбомир МеАвіАь. Живопис. Каталог виставки / авт. вст. ст. і упор. О. Пеленська; Упр. культури Аьвів. облвиконкому; СХ УРСР; Аьвів. карт. гал. Аьвів: [б. в.], 1987. С. 3.

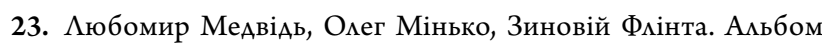
/ упор. О. Жирко-Козиркевич. Київ: Мистецтво, 1992. 243 с.

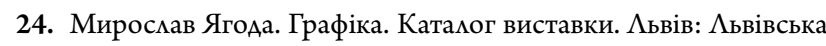
нац. гам. мистецтв ім. Б. Г. Возницького. 2019. 82 с.: іл.

25. Мирослав Ягода. Живопис. Каталог виставки. $\Lambda$ ьвів: $\Lambda$ ьвівська нац. гал. мистецтв ім. Б. Г. Возницького. 2019. 146 с.: іл.

26. МеАвіАь $\Lambda$. Генезис. Каталог виставки / Аьвівський палац мистецтв; $\Lambda$ ьвівська національна галерея мистецтв ім. Б. Возницького. Аьвів: [6. в.], 2016.35 с.: іл.
[I always dressed stylishly because I sewed for myself]. Vysokyi Zamok. https://wz.lviv.ua/interview/387089-ya-zavzhdy-stylno-odiahavsia -bo-sam-sobi-shyv

18. Mykhailo Bezpalkiv. Albom (2012). [Mykhailo Bezpalkiv. Album]. (n. p.).

19. Medvid, L. (2015). Parad parabol. Albom. [Parade parable. Album]. Kolir PRO.

20. Ostrovskyi, H. (1981). Lubomyr Medvid, Oleh Minko, Zenovii Flinta. Kataloh. [Lubomyr Medvid, Oleg Minko, Zenovia Flinta. Catalog]. Oblpolihrafvydav.

21. Lubomyr Medvid, Oleh Minko, Zenovii Flinta. Zhyvopys. Kataloh vystavky (1986). [Lubomyr Medvid, Oleg Minko, Zenovii Flinta. Painting. Exhibition catalog] Sovetskyi khudozhnyk.

22. Lubomyr Medvid. Zhyvopys. Kataloh vystavky (1987). [Lubomyr Medvid. Painting. Exhibition catalog]. (n. p.).

23. Lubomyr Medvid, Oleh Minko, Zynovii Flinta. Albom (1992). [Lubomyr Medvid, Oleg Minko, Zinovii Flinta. Album]. Mystetstvo.

24. Myroslav Yahoda. Hrafika. Kataloh vystavky (2019). [Myroslav Yagoda. Graphics. Exhibition catalog]. Lvivska nats. hal. mystetstv im. B. H. Voznytskoho.

25. Myroslav Yahoda. Zhyvopys. Kataloh vystavky. (2019). [Myroslav Yagoda. Painting. Exhibition catalog] Lvivska nats. hal. mystetstv im. B. H. Voznytskoho.

26. Medvid, L. Henezys. Kataloh vystavky (2016). [Genesis. Exhibition catalog] Lvivska natsionalna halereia mystetstv im. B. Voznytskoho.

Bratiuk N.

Expressive and Pictorial Language and the National Orientation of Creative Experiements of the Lviv Artists in the 1980s: L. Medvid, M. Yagoda, M. Bezpalkiv

Abstract. The article addresses expressive and pictorial means in the works of Lviv artists of the 1980s L. Medvid, M. Yagoda, M. Bezpalkiv, who were iconic and famous figures of the second half of the twentieth century in the artistic life of Lviv, Ukraine, and abroad. Their works differ significantly against the background of the artistic context, the paintings operate deep spiritual and moral and aesthetic values, images from Ukrainian mythology, and are marked by professionalism and unique style. The aim of the research is to view the 1980 s paintings by L. Medvid, M. Yagoda, M. Bezpalkiv in the context of the expressionist vector of development. Research methodology includes art analysis, comparative method, method of analysis and synthesis, formal analysis of stylistic features of the authors' styles. In the process of complex research, the socio-cultural, artistic and political preconditions that led to the emergence and formation of expressive features in the works of L. Medvid, M. Yagoda, M. Bezpalkiv were clarified. It was discovered that the painting of Lviv-based artists in the 1980s significantly influenced the present-day art of Lviv.

Keywords: artists of the eighties, L. Medvid, M. Yagoda, M. Bezpalkiv, expressive and pictural language, painting.

Братюк Н.

Экспрессивно-живописная язык и национамьный вектор творческих поисков мьвовских художников 1980 годов:

М. МеАвеАь, М. ЯгоАа, М. Беспалько

Аннотация. Исследуются экспрессивно-живописные среАства в творчестве Аьвовских художников 1980-х годов $\Lambda$. МедвеАя,

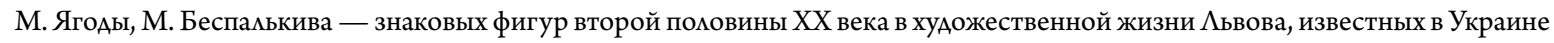
и за границей. Их работы существенно вылеляются на фоне художественного контекста, полотна апемлируют к глубоким духовным и нравственно-эстетическим ценностям, украинской традиции и мифологии, отмечаются профессионализмом и собственным стилем. Целью статьи стало исслеАование живописного творчества А. МеАвеАя, М. ЯгоАы, М. Безпалькива 1980-х гоАов в контексте экспрессионистического вектора развития. Проанализированы полотна, в которых экспрессионистические составмяющая зарожАается или отчетливо прослеживается. Собранный визуальный материал, а также научные публикации, касающиеся творчества вышеупомянутых художников, вместе образуют уникально широкую картину художественных процессов того времени. В методике исслеАования использованы искусствоведческий анализ, сравнительный метоА, метоА анализа и синтеза, формальный анализ стилевых черт авторского живописного почерка. В процессе комплексного исследования выявлены социокультурные, художественные и политические преАпосылки, которые привели к появлению и становления экспрессивных черт в творчестве $\Lambda$. МеАвеАя, М. ЯгоАы, М. Безпалькива. Было установлено, что живопись этих художников 1980-х годов суще-

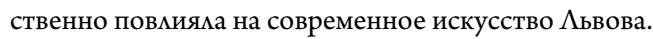

Ключевые слова: восьмидесятники, $\Lambda$. МеАведь, М. ЯгоАа, М. Беспалько, экспрессивно-живописная язык, живопись, Аьвовские художники. 